\title{
Wajdi Mouawad, Forêts
}

\section{Veronica Cappellari}

\section{(2) OpenEdition}

\section{Journals}

\section{Edizione digitale}

URL: https://journals.openedition.org/studifrancesi/46420

DOI: 10.4000/studifrancesi.46420

ISSN: 2421-5856

\section{Editore}

Rosenberg \& Sellier

\section{Edizione cartacea}

Data di pubblicazione: 1 octobre 2007

Paginazione: 490

ISSN: 0039-2944

\section{Notizia bibliografica digitale}

Veronica Cappellari, «Wajdi Mouawad, Forêts», Studi Francesi [Online], 152 (LI | II) | 2007, online dal 30 novembre 2015, consultato il 24 novembre 2021. URL: http://journals.openedition.org/studifrancesi/ 46420 ; DOI: https://doi.org/10.4000/studifrancesi.46420

Questo documento è stato generato automaticamente il 24 novembre 2021.

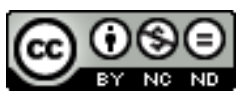

Studi Francesi è distribuita con Licenza Creative Commons Attribuzione - Non commerciale - Non opere derivate 4.0 Internazionale. 


\title{
Wajdi Mouawad, Forêts
}

\author{
Veronica Cappellari
}

\section{NOTIZIA}

WAJDI MOUAWAD, Forêts, Montréal/Arles, Leméac/Actes Sud-Papiers, 2006, pp. 108.

1 Forêts di Wajdi Mouawad, autore e regista di origine libanese emigrato in Québec negli anni Novanta, è la terza parte di un ciclo drammatico inaugurato nel 1999 con Littoral (Montréal/Arles, Leméac/Actes Sud-Papiers, 1999) e proseguito con Incendies (Montréal/Arles, Leméac/Actes Sud-Papiers, 2003). Rappresentata per la prima volta il 7 marzo 2006 presso l'Espace Malraux, Scène nationale de Chambéry et de la Savoie, Forêts tratta principalmente i temi della discendenza e dell'ereditarietà.

2 La protagonista delle vicende rappresentate è Loup, una coraggiosa adolescente che tenta di far luce sulle proprie origini materne e sull'oscuro mistero che avvolge il singolare e anomalo tumore sviluppatosi nel cervello della madre: una sorta di corpo solido, con le caratteristiche di un osso appartenuto a una donna morta in un campo di concentramento durante la Prima Guerra Mondiale, che si rivela poi essere l'embrione fossilizzato del suo gemello. A fare da cornice a questo intricato e inconsueto evento vi sono sei donne, vissute in epoche differenti, le cui storie e i cui destini iniziano a mescolarsi e a confondersi, dando origine a un viluppo inestricabile fatto di amori impossibili, di tradimenti, di incesti e di abbandoni materni: da Odette a Hélène, da Léonie a Ludivine, da Sarah a Luce e, infine, ad Aimée, madre di Loup, attraverso la quale viene ricostruita, scena dopo scena, la loro oscura discendenza.

3 Se per certi aspetti la pièce può apparire di taglio puramente fantastico e immaginario, per altri versi, tuttavia, recupera un'impronta piuttosto realistica, rievocando alcuni tra i più tragici eventi storici che hanno caratterizzato il xx secolo: la Prima e la Seconda Guerra Mondiale, i campi di concentramento e la caduta del muro di Berlino. La pièce, come afferma l'autore nella prefazione, è stata rimaneggiata e perfezionata più volte in seguito alle varie rappresentazioni sceniche. Il punto d'arrivo è scrittura, ora diretta e quasi documentaria nel suo realismo, ora solcata da una sensibile vena 
poetica, che fa di Wajdi Mouawad uno degli autori più autorevoli ed apprezzati del teatro quebecchese francofono contemporaneo. 